\title{
Nara Dillon and Jean Oi, (eds.), At the Crossroads of Empires: Middlemen, Social Networks, and State- Building in Republican Shanghai.
}

\section{Marie-Claire Bergère}

\section{(2) OpenEdition}

\section{Journals}

Édition électronique

URL : http://journals.openedition.org/chinaperspectives/4864

DOI : 10.4000/chinaperspectives.4864

ISSN : 1996-4617

Éditeur

Centre d'étude français sur la Chine contemporaine

\section{Édition imprimée}

Date de publication : 1 septembre 2009

ISSN : 2070-3449

\section{Référence électronique}

Marie-Claire Bergère, « Nara Dillon and Jean Oi, (eds.), At the Crossroads of Empires: Middlemen, Social Networks, and State-Building in Republican Shanghai. », China Perspectives [En ligne], 2009/3 | 2009, mis en ligne le 16 octobre 2009, consulté le 24 septembre 2020. URL : http:// journals.openedition.org/chinaperspectives/4864; DOI : https://doi.org/10.4000/chinaperspectives. 4864

Ce document a été généré automatiquement le 24 septembre 2020.

(c) All rights reserved 


\title{
Nara Dillon and Jean Oi, (eds.), At the Crossroads of Empires: Middlemen, Social Networks, and State-Building in Republican Shanghai.
}

\author{
Marie-Claire Bergère
}

1 Another book on Shanghai and its history! This one brings together several chapters produced by veterans of Shanghai studies and by some newcomers: young historians or experienced specialists from other fields, such as Jean Oi. Its aim, the authors tell us, is "to look at Shanghai with fresh eyes" (p. 5): what kind of cement is it, they ask, that ensures the cohesion of a city that is divided into several communities, that prospers "at the crossroads of empires" (Chinese, British, and French), and that evades to a large extent the control of a national government? It is necessary to seek the answer in the pivotal role played by rich and notable citizens who, combining several activities economic, philanthropic, cultural, and political - provide the link between the various networks that structure the urban society. Far from putting the brakes on the construction of a modern state by concealing the division between society and power, the co-operation negotiated by these Shanghai notables, including triad bosses, with government officials offers a specific and effective model of public/private partnership in the service of the general population.

2 These themes, in reality, are not new, and are taken up again here by historians who were among the first to identify and explore them. Brian Martin tells us once more of the significance of the role played by Du Yuesheng and the Green Gang (chapter 4), while Yeh Wen-hsin recounts the importance of the campaign led by the educator Huang Yanpei and his Vocational Education Society (chapter 2). Parks Coble recalls for us the unifying role of the National Salvation Movement (chapter 6), and Jefferey Wasserstrom gives us portraits of Shanghai cosmopolitans capable of forging links 
between foreign and Chinese communities (chapter 10). Elizabeth Perry expands her reflections on the world of the working class, attempting to define how the networks of traditional solidarity came to act in harmony with the parties endowed with an ideology and a political programme during the mass mobilisations of 4 May 1919 and 30 May 1925, and the revolutionary strikes of the autumn of 1926 and the spring of 1927 (chapter 5). Bryna Goodman continues her study of regionalist associations by analysing the way in which they adapted to the new political context of the $1930 \mathrm{~s}$ (chapter 8).

3 The young historians contribute the fruits of their recent research. In chapter 3, Kuiyi Shen pursues an interest in the personality of Wang Yiting, businessman, philanthropist, painter, devout Buddhist, and political player. Any historian who has studied Shanghai will inevitably have come across this omnipresent notable in the years from 1910 to 1930, but to my knowledge this is the first time that the complicated web of his activities and his relationships, the crisscrossing of the multiple associations that he founded, led, animated, and financed, has been untangled in this way. One can only admire the patience and the attention to detail that the author applies to reassembling the pieces of the puzzle. An accumulation of factual information, the chapter makes for somewhat austere reading, but offers a precise and concrete illustration of the realities referred to by the much bandied term of guanxi (personal relations).

4 By studying the trial instigated in 1935 against the magazine New Life Weekly (Xinsheng Zhoukan) and its editor Du Zhongyuan, Sei Jeong Chin illuminates the mechanisms that allowed a violently anti-Japanese publication to survive during several years of rigorous censorship imposed by the government of Chiang Kai-shek, which was compelled to exercise a policy of appeasement with regard to the invaders (chapter 7). The interdependence that existed between government officials, the political elite, and journalists blurred the differences between state and society at the same time as it gave the political opposition the possibility of expressing itself.

5 In her vigorous essay on "The politics of philanthropy" in Shanghai from 1932 to 1949 (chapter 9), Nara Dillon analyses the concerted contributions of social networks and government agencies in the organisation of aid for victims of the Japanese invasion, civil wars, economic crises, and natural catastrophes. She shows how much the action of the public authorities owed to these associations in the 1930s and how the weakening of these associations and their leaders after the Second World War led to the illusory victory of a welfare state that wanted, but was unable, to take on by itself the responsibility for its social policy.

6 As much as they are variations on already known themes, these contributions clarify and enrich; without being genuinely fresh, the eyes are sharp. It can be asked, however, whether the analysis does not meet its methodological limits here. It is one thing to assert that the functioning of society is based on the pivotal role played by some rich and charismatic personalities; it is another to decipher the accumulation of the multiple contacts and processes on which the actions of such personalities are based. The story of guanxi lies in the details, the specifics, the imponderables. But are historians and their readers really ready to welcome a return to the historical chronicle?

7 Translated by Nick Oates 